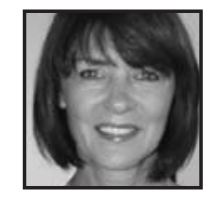

\title{
Reinvigorating Conceptions of Teacher Identity: Creating Self-Boxes as Arts-Based Self-Study
}

\author{
Ruth Leitch, Queen's University Belfast
}

\begin{abstract}
This paper presents a palimpsest of ways in which self-study draws upon arts-based methods not just as processes towards teacher development, but also as means to problematize and inquire into conceptualizations of the self. It focuses on the creation of individual self-boxes that mediate teachers' dynamic narratives of identity. Concepts of the unitary self, the decentred self and the relationship between inner and outer experience are challenged and illustrated through two interlapping stories made manifest through the creation of self-boxes.
\end{abstract}

From time immemorial man has known that he is the subject most deserving of his own study, but he has also fought shy of treating this subject as a whole, that is, in accordance with its total character. (Buber, 1947, p. 140)

\section{Beginning Fragment}

knew exactly what should be placed at the centre. The image was there before the naming, as I sat alone that late, autumnal Saturday morning, staring at the opaque inner space between my "work of art" and the view outside the university window. A water lily. Simple in its beauty, yet vibrant, dynamic, iridescent with sepals of flame curling inward. A feast of light and form. Rooted yet floating free. Timeless. Yes, this was to be the centerpiece of my self-box - a creative task that was coming near the end of my two-day concentration. I could just about hold the image's mystical, kinetic beauty in my mind's eye. A sharp exhalation of breath, my own, brought me back from the vision and out to the view of the Theological college beyond the window. Darn. Reality! 
How to fashion this image, so that it might look as I held it in my imagination? If this could be achieved, I could then place this final piece in the centre of the self-box where it belonged. This would bring to fruition this construction of self. My Self. The trouble was I was no real artist. Rather, I had been working intuitively, all the weekend, using paint, artifacts, magazines, craft materials gradually to portray various aspects of myself inside and out on a cardboard shoebox that had once housed a pair of my size 38 trainers, long since worn out from road running.

\section{Self-Boxes}

Frings Keyes (1983, p. 14) describes the making of a self-box as forming "a visible graphic record of your perception of you" and where reality is integrated with fantasy. This has been used as an art technique, originally deployed in psychotherapy with troubled clients, but also, more recently, with nonartists as a means to deeper awareness about how we as individuals participate in creating life's conditions. According to the art therapeutic tradition, using art materials vivifies the process of self-exploration, reaching different levels of the personality more adequately than can words alone. Within a differing domain, Janesick (1998) suggests the use of a "YaYa Box" or "Self-box" as a research technique to develop and capacity-build qualitative researchers. Making a self-box, she feels can serve to "represent a person's innermost self on the inside of the box and the outward self on the outside of the box" (p. 50) and, using the metaphor of dance, she recommends that researchers themselves should engage in art-making as a form of "stretching exercise" in order to ensure that anyone who engages becomes a "stronger, more flexible and more fluid researcher" (p. 14). Honing intuition, developing receptivity and reciprocity as well as sensitivity to interpretation are essential attributes for undertaking delicate, in-depth qualitative and arts-based research and it was largely with these aspirations in mind that I undertook the task of making my own self-box, while engaging in a research project on teachers' identities. Three autoethnographic fragments of self-dialogue interweave throughout this script to tell a little of the creative process of self-box making and capture an epiphanic moment that changed the way I viewed myself.

I originally adapted the making of self-boxes in the 1990s as a teacher development activity, opening up creative pedagogical spaces in university teacher programs. Being concerned with the continuing professional development of teachers involved in pastoral dimensions of schooling and curricula, and from knowledge I had gained as a clinical psychologist, I based these programs on the belief that good teaching and good practice come from a teacher's identity, not technique. As Palmer 
(1998, p. 63) says, teaching always takes place at the crossroads of the personal and public:

Teaching, like any truly human activity, emerges from one's inwardness, for better or worse. As I teach, I project the condition of my soul onto my students, my subject, and our way of being together. The entanglements I experience in the classroom are often no more or less than the convolutions of my inner life. Viewed from this angle, teaching holds a mirror to the soul.

Creative or arts-based activities, such as collage, mask work, painting, sculpting and the creation of self-boxes act as vehicles for teachers' various explorations and the self-knowledge that derives from the narratives reflected within and mediated through dialogue with such artifacts. I have sympathy with Gergen and Gergen (1988) who make a case that the teaching profession should, at both the individual and collective levels, acknowledge the importance of professional self-narratives in order to unpick the profound connection between identity and practice. Engaging with art materials, for those teachers who participate, seems to vivify these processes and the creation of an individual self-box, in particular, appears to stimulate significant and deep layers of meaning that might not be readily represented by using language (dialogue and reflective writing) alone. Experience with teachers over time taught me that the synergy between arts-based activities and forms of creative writing and dialogic encounter opened up imaginative spaces for teachers to develop their self-narratives, often provoking a renewed sense of their professionalism in the process (Sachs, 1999). Only later in my career, did I claim arts-based processes (including self-boxes) as legitimate means to inquire into specific questions that intrigued on teachers' self-identities through creative narratives (Leitch, 2003, 2006).

"The art work opens up in its own way the Being of beings. This opening up, this de-concealing i.e. the truth of beings happens in the work." (Heidegger, 1971, p. 39)

Using self-boxes as inquiry is similar in some senses to collage as inquiry as at the most practical level it involves the "process of cutting and sticking found images fragments from popular/print magazines" (Butler-Kisber, 2008, p. 265), in this case, onto a cardboard box of selected dimensions. Beyond the technical side, at a symbolic level, there are conscious and unconscious choices associated with the artistic process of what is located where and in what form: shape, texture, color and with what relationship. In these ways, the creation of a self-box, as with collage, expresses "the said and the unsaid, and allows for multiple avenues of interpretation 
and greater accessibility" (p. 268) but through a more complex, three-dimensional, embodied form. Slattery (2001) and McMahon (2000), independently, offer provocative examples of how intuitive, nonconscious knowing finds form in aesthetic representations, and these aesthetic representations are, in turn, probed with considerable reason to yield insights into self, other and arts-based educational research (Piantanida, McMahon, \& Garman, 2003, p. 199).

\section{Middle Fragment}

There is something breathtaking about fashioning clay: rolling, cutting, molding, sculpting, building. Damp and intricate but oh so delicate. It was taking shape, my water lily; perhaps more sea anemone here and there with the frond-like sepals pointing heavenwards but its form was beginning to take on some semblance of my visual image. Handbuilding porcelain is no easy task. Porcelain clay, when mixed with water, forms a fine plastic paste which can be worked to a required shape that ought then to be hardened and made permanent by firing in a kiln at temperatures of between 1200 and 1400 degrees Celsius. Mine was a labor of love mixed with large dollops of painstaking determination. I didn't have access to such a kiln. So my lily would have to remain "green," airdry naturally, exist forever brittle, and be painted subsequently in the colors of fire to form the heart of my self-box.

\section{Self and/or Memory Boxes}

The concept of self-boxes is somewhat allied but still distinctive to the burgeoning interest in and role of memory work which incorporates the creation of memory books and memory boxes for particular, personal, social, historical and therapeutic purposes. Memory work, in this sense, is related to identity work often associated with displaced persons, such as orphans, adopted children and refugees. hooks $(1989$, p. 17) contends that the purpose of memory work is to make the past usable so that remembering "serves to illuminate and transform the present." Memory boxes are containers, though not necessarily boxes, in which adults and/or children can store versions of personal, family or community history likely to be of importance to themselves, surviving family members or future generations. They became popularized by charitable and aid organizations in the early 1990s, in response to the widespread HIV/AIDS crisis in places such as Africa, providing simple and tangible processes by which ill parents could record their family history as an aid to helping their children deal with loss. From their experiences in South Africa, Thomas and 
Morgan (2002) report that memory books or boxes created by parents to help children build an identity and strengthen their emotional capacity, assist them to understand the past and to face the future in the circumstances of the ongoing and painful epidemic.

Based on the idea that childhood memories are important in helping to determine our identity and values as we grow older, memory boxes have also been used extensively in projects to support those with dementia where boxes filled with cards, photographs, crafts, war-time memorabilia, models, books, mementos and toys help to focus the attention of sufferers, securing a sense of connection to their personal histories and threatened identities. Through sensitive and ethical use, dialogue with others about these memorabilia opens up narrative elements of lives lived and, as such, memory boxes also create spaces for generating rich written, visual and taped accounts and legacies of people's lives. Harrison (2002), for example, argues that using family photographs can provide a powerful basis for narrative work, since they are preserved memories that illustrate the person's life or provide a way of communicating who they are and where they have come from and narration is an important means by which lived experiences are rescued from oblivion. As Kotre $(1995$, p. 17) says, such interaction allows us to "touch old objects, smell old aromas; hear old sounds...to recapture the experience of childhood..."

\section{Self-Study}

Self-study, or self-inquiry, is viewed as an important component in the desire for teachers to have increased understandings of their identities as practitioners and their pedagogical practices. In its broadest sense, self-study is conceptualized by Bodone, Guojónsdóttir and Dalmau (2004) as combining the social construction of knowledge, reflective practice and action for social change. It is also linked to ideas about developing better knowledge through increased self-awareness and/or understanding of personal experience and thereby to transformation and change in both professional self-identity and related practices.

Teaching, like any truly human activity, emerges from one's inwardness, for better or worse. As I teach, I project the condition of my soul onto my students, my subject, and our way of being together. The entanglements I experience in the classroom are often no more or less than the convolutions of my inner life. Viewed from this angle, teaching holds a mirror to the soul. (Palmer, 1998, p. 2) 
Recognizing the dissonance between beliefs and practices so that these may become better aligned is key to the process of self-study. While recognizing the positive professional development impact of self-study on teacher educators, and the importance of hearing practitioner voices, Zeichner (2007) calls for more closely connecting self-study to the mainstream of teacher education research.

Thus, despite being seen as occupying marginal boundaries in the academic of educational research, self-study is increasingly associated with methodologies that are considered different from other approaches to teacher development or, indeed, traditional research methods. Self-study that embraces visual and arts-based approaches to teachers' self-study and change, borrows methods from the arts and humanities including the visual arts, memory-work, literature, poetry and drama, arguing that these approaches allow teachers to follow their own "poetic (and visual) sixth sense" (Diamond \& van Halen-Faber, 2005; p. 81, [mis]-quoting Seamus Heaney) in order to make public the wisdom of their personal practical knowledge and teacher-selves. These arts-based methods of inquiry still wrestle for mainstream acceptance in the world of educational research but are nevertheless rich in their capacity to create opportunities for teachers to reflect and self-direct, and there are many examples that attest to this.

Mitchell and Weber (1999), in wishing to understand both the "darker and lighter" aspects of teachers' work, explore the use of photography, written memoirs, movies and video in order to focus on specific aspects of the teaching self. They draw on the creative power of images, memories, everyday details, technology, and nostalgia in unexpected or unconventional ways. "Through stories about our own and other teachers' struggles for self-knowledge and identity," they suggest ways "to investigate and reinvent teacher identity and practice" (pp. 1-2). Later, Derry (2005) describes her use of drawing in self-study to uncover deeper embodied descriptions about her experiences of being bullied as a child, while Biddulph (2005), for instance, develops a visual methodology, by means of photography and mural-making, to represent and review layers of his experience of being both gay and a teacher.

In many definitions of teacher self-study and reflective practice, there is continuing appeal to the "self" of the practitioner. "Who is the self that teaches?" is a rhetorical question at the heart of this approach to self-study (Palmer, 1998, p. 7) and, of course, any response is not without challenges and complexities. While many of us still rely on notions of a "core" or coherent sense of self, other writers have begun to deconstruct what they term modernist fantasies about unified selves evolving in a world of technological progress (Lorenz \& Watkins, 2001). The "self" is now 
conceptualized as more fragmented and incomplete, composed of multiple selves or possible identities that we inhabit as we negotiate and traverse differing personal and social contexts (Atkinson, 2002). This "decentred self" has no enduring or "essential" identity; and if we appeal to such in our self constructions then, it is argued, this is simply part of our "narrative of the self" and, of course, narratives are themselves the product of social interaction. Given the various tensions alluded to, there are those who fear that self-study will be transformed into inquiry that ignores the self and looks only to the practices of the teacher (Cole, 1997); while other critics argue that self-study falls on the wrong side of narcissism and solipsism (Coffey, 1999). In the face of all this, self-study too often occupies an interstitial space in teacher development and educational research, but rather than succumbing to views of it as self-absorbed or redundant, arguments about the saturation and dislocation of the self should serve only as imperatives for us, as teachers and teacher educators, to listen in to our own paradoxes and ambivalence rather than to turn a deaf ear to the multiplicity of voices and inner dialogues. Despite the paradoxes experienced through handling contradictions, fragmentation and conflicts in their personal and professional lived experience, accounts of teachers' professional experiences and practice frequently make reference to a functional (professional) self as agent, and self-study in its various forms has a key role to play in this.

Thus, while not having started out as such in my own professional work, I now argue that taking on our own self-study frequently becomes a political project (as well as an individual, psychological one) whereby we can interrogate the present and the past conditions of our personal and professional lives, listen to our selves and others, deliberate, consider evidence and options and recast understandings in preparation for change and development. Self-boxes are but one example in a myriad of creative and arts-based processes that permit an entrée to the crucial and continuing self-study project for teachers.

\section{Self-Box Process}

Making self-boxes is designed as a major element of one of the university teacher development courses I offer at the masters level, the content of which focuses on teachers' facilitation skills for the personal development of students through the curriculum. Within the course program, the goal of this specific artsbased, creative task, is to facilitate self-study with teacher participants, in order to explore if, using this simple form, they consciously and/or unconsciously, create representations of their self that symbolize different "sides" to the(ir) self, (or identities) and what significance and significations, if any, they attribute to these constructions 
both personally and professionally. Although not set out in a structured fashion, there are processes to this self-study activity that engage participants in (i) exploration inspiration - creation, (ii) dialogic interanimation - sharing. What is crucial to the effective use of these processes however is to see them as simply descriptive and that they are never treated as linear or stage-like but rather overlapping and recursive. They must also be engendered within pedagogical spaces conducive to the development and maintenance of quality and trusting relationships.

\section{Exploration - Inspiration - Creation}

Kalff (1980), in a psychotherapeutic context, talks of the vital importance of a free and protected space outside everyday routine, in which to encounter and dialogue with whatever new images and events emerge spontaneously in our inner and outer worlds. A key element of this is to set a respectful, yet natural atmosphere for the task which is purposeful, ethical and carefully negotiated with all persons involved. Emphasis is therefore placed on creating a safe and contained space, in which teacher participants can engage playfully and meaningfully in their individual exploration of the artistic media leading to self-box creation. This dimension of the program is thus planned minimally for a full day, often as a weekend workshop, in which there is time, space and a sense of collective commitment and endeavor by the group of ten to twelve teachers who attend. Iterations of this element of the program over time, demonstrate that the self-box task leads to a creative act of absorbed concentration that endures for hours or longer for all participants involved, even those who originally protest or negate their artistic ability.

\section{Dialogic Interanimation — Sharing}

Once the creative process has come to a point of satisfaction, then begins an ongoing process of self-narration. Thereafter, the self-box acts as a discursive resource at both individual and collective levels, a resource which scaffolds the development of the teachers' self-narratives over time. Wertsch (2001) talks of the importance of dialogic interanimation which opens up spaces within and between people and, in this case, between the teacher and his/her self-box, where incommensurately differing or multiple perspectives and uncertainties may be held and explored simultaneously.

In this self-study experience, teachers are supported to deepen their critical reflections on aspects of their self and any dynamic relation of these to their personal and professional development through discussions with myself as mentor, the other teachers and through exploration and dialogic interanimation of the symbolic aspects of the self-box, by means of self-reflection, creative writing, poetic renderings, 
memoing and journaling. Through this scaffolding, the participants gain differing perspectives from this creative work, which lead to various understandings of what they are and what they can become from multiple points of view. As these discourses about the self are fashioned, it becomes evident that this narrative work is not simply monologic, but polyphonic presenting a "syllabary of possible selves" (Gergen, 1994, p. 193). Through this process, teachers construct, among other things, potential relationships between representations of "internal" (personal) and "external" (professional) and whether or not they identify any sense of "core self" over time:"That is not to say that life copies art, but rather that art becomes the vehicle through which the reality of life is made manifest." (Gergen, 2001, p. 248)

What follows is a case illustration by one participant, Kathy, a senior and experienced teacher, who participated in the self-study program. In this, she shares excerpts from her narrative of identity and through the co-creation of the representation, we witness some of the ways dialogue with self, others, and her self-box, helped her to articulate and reconfigure aspects of her personal and professional identity through creative writing.

\section{Kathy's Self-Box}

From an early stage I would say I wanted to be a teacher. From [the time] I was ten or eleven years old. Before that, I wanted to be a detective, but after that, nothing would have deviated me from it. I wanted to be a primary school teacher.

With regard to her identity as a teacher, Kathy describes herself from the outset as being driven by a philosophy in teaching that has at its core such principles as "inclusion," "democracy in the classroom" and the importance of encouraging and listening to the "child's voice." Her capacity to "speak out" on behalf of others is and always has been a significant part of her professional identity. 


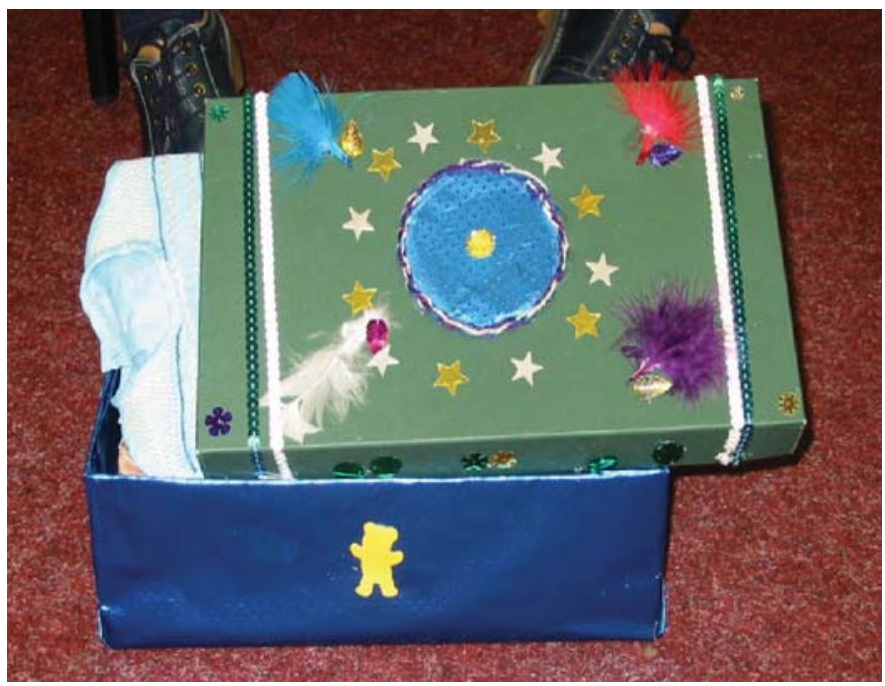

Fig. 1: Self-box

\section{Kathy's' Self-Box (Outer)}

Kathy's self-box is an Aladdin's-cave experience, a veritable cross between memorybox and self-box. While the top of the box was orderly and mandala-like, leading her to reflect upon her considered relationship between spirituality and church-based religion, the inside is completely different. It "needs to be folded but not ordered," she reflects. It is chock-full of layers of significant and tangible symbols of Kathy's life story, like an autobiographical time line in embodied form. The intricacies of the box, unpacked from their orderly arrangement, take up considerable physical space and narrative time, where photographs play a significant role in re-creating past events and feelings, as she interacts with the materials through dialogue and journaling over a period of months.

\section{Dialogic Reflections}

The two aspects of me that I struggle with most strongly when I sit with my self-box are my need for things to be clear, ordered and straight (well, at least in my outer lived world) and my compunction to speak out on where things are wrong or where [individuals] cannot defend themselves and how this constantly gets me into trouble, bringing me into conflict, usually with men in authority-especially within my roles in schooling. 
Suddenly everything seems symbolic although I had no idea at the time. Why did I put my mandala on the outside of the box? I like things natural so I retained the box as natural; it's natural green, the deep, deep green of the sea, near where I spent some significant time when I grew up. My symbols are the two straight sequined lines on each side because I do like things ordered. Then, in the centre, the blue circle, foil paper deliberately chosen because it was reflective and a colour, not dissimilar to the dress I recently wore on New Year's Eve, borrowed from my daughter, shiny blue and such a challenge to my partner who said it was inappropriate for my age. The stars, twelve in number, like the Apostles, not at the time but now I see these as representing the church, Christianity and my struggle with these. The yellow-golden ball at the centre-it is important that it was shiny and radiated like my sense of core, my energy. Round the outside of the blue circle I placed a hand-woven friendship bracelet which I took time to weave while making my box, thinking about the important role of friendship and community to me, given how fragmented my childhood was with the endless house moves associated with my father's job.

\section{Exiled: a Found Poem}

On the outside

I wear my core

Or so it seems

Displaced?

I wonder.

Organized religion

Out of love

I fell with this.

Once a woman

Of the church.

Not priest

More lay.
But there

Always there.

Too many rules

Too little love.

He was a man of God

He named and shamed.

I spoke out

In anger

And left.

One day

I hope to return...

Home.

Reflections of her tense relationship between her sense of spirituality and organized religion led Kathy to understand differently her passion for an ecumenical approach within schools and her current commitment to education which promoted mutual understanding and multi-faith religious education. 

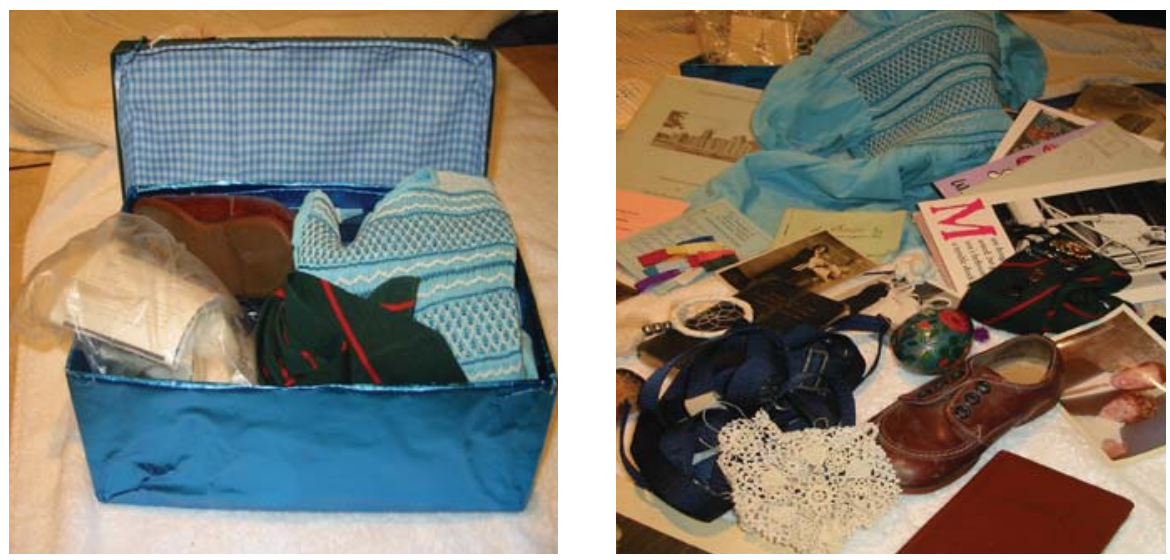

Fig. 2: Kathy's self-box (inner box and contents)

Through the use of the art-making, memoing and reflective process that ensue, some unexpected emotional episodes appear symbolized in Kathy's self-box. The relationship between external happenings and internal self-experience is made more lucid, not only in terms of her personal but also her professional life. Kathy describes this as not just a rational understanding but more a re-living, and therefore, re-evaluation of the previous memories. The insecurity deriving from early house moves as a child, for example, is seen as being counteracted by the security of the processes of schooling and teaching as a "secure job" to which she has committed herself.

Dialogue-stimulated by a variety of self-box images, symbols and memorabilia, including early biographic photographs-led Kathy to become aware of (sometimes for the first time) connections between early experiences and the passion that fuels her causes and sense of moral purposes as a teacher. Although emotionally painful to acknowledge, Kathy also links these early critical incidents to her commitment to speak out against mistreatment and to challenge, on behalf of children, anything she feels is wrong or unjust and to insist that children should be given opportunities to speak directly on behalf of themselves.

About the self-study process she says:

Talking versus creating?.... it would have been more general rather than specific. I wouldn't have taken the time to do it before.... Definitely, you know how much I hate art. So the art business I have a thing about, but it wasn't threatening. It 
wasn't going to be looked at for its artistic quality. It was what would be of significance to me. If I hadn't taken the time out to be looking at it (symbolic images and mementoes) and if I hadn't created it and looked at it afterwards... and wrote...then I wouldn't have known...I can truly say that it [self-box] raised issues which would not otherwise have been talked about in interview nor reflective writing alone. I could not deny what was clearly depicted in front of me and I was the only one who could explain what was there.

Finally then, Kathy attributes significant meaning to the creative research process of making her self-box and, in so doing, articulates a narrative of identity around axes of family and work and where she holds previously unspoken tension about her religious as opposed to spiritual sense of centre. Her explicit narrative emphasizes her common-sense, practical busy, pragmatic and determined approach to her personal and professional life but engaging in the creative narrative process explores new possibilities for change as she uncovers strong emotional seams of fear and anger, which appear to have been interwoven into her identity, although hitherto unappreciated by her.

"The self exists as a process in a constant state of transformation and flux: it is the dialogue between the facets." (Ronai, 1992, p. 107)

\section{Reflections on Self-Box Inquiries}

The creation of self-boxes, as visual three-dimensional representations of self and identity, is illustrative of one way in which teacher self-study can draw upon arts-based methods. The excerpts from two individual self-study processes are intended to illumine how engaging in the creative act of self-box making and the ensuing dialogue can stimulate re-conceptualizations that have impact on individual and collective teacher development. Kathy's story of herself in relation to her self-box leads to thick descriptions of various aspects of her experience both personal and professional over time. These are replete with many unintended discoveries including references to differing sides, differing facets, differing voices, fragmented aspects and sometimes oppositional selves in the conversations and writings about her self-box. In particular, her self-narratives follow themes concerning her relationship between her spirituality, her religious sense of decentredness and what this means in terms of her passions, directions and ambivalences in education. Deep emotional patterns and their influences were excoriated in terms of childhood experience and her positioning as a white, middle-class woman in education at this time and in this culture which, as these develop, allow her to reevaluate choices about how she acts in relation 
to various challenges in her professional roles. For my own part, the final narrative fragment captures a poignant moment of collusion with an "inner imposter" deemed necessary at that time in order to protect my fragile sense of "core."

"Neither should the present propensity for hailing multiple identities as the new order blind us to the importance of deep attachments for a coherent sense of one's own social and moral identity." (Conroy, 2007, p. 5)

Of course we (Kathy, myself and the multitude of other teachers who have engaged in such self-study activities) may simply be applying our saturated modernist views; having an "image" of ourselves as subject, as if the self was a "real object" and postulating a "deep centre of identity" (Whitmore, 2000, p. 8) from which preexistent knowledge is uncovered rather than constructed. By contrast, I would argue that by means of the creative act and the dialogic interanimation with the final object, in this case the self-box, we do not foreclose possibilities of self and identity. Rather, we engage in "I-Thou" or "I-It" dialogues which encourage accounts of different or multiple selves, and where there is more than one story to tell. Facets, it seem, carry different aspects of self, cover different stories and dimensions of stories that lead to rich and open-ended narrative possibilities. Thus, the glimpses of self-inquiry we offer here, though partial, raise possibilities on how the use of self-boxes problematize and allow for deeper contemplation into theoretical conceptualizations of self and identities as well as holding capacity to rupture the ordinary in creative ways.

What the artifice of a self-box provides uniquely as an arts-based method, it seems, is the faceted, multidimensional and symbolic nature of its form. This enables questions of the self to be examined in terms of "inner" and "outer" (including those bits of the self that are in/visible and un/knowable to the external world, self and other) and in terms of centre, sides or selves. These crystallized images of the imagination are in a sense externally embodied and, in Vygotskian (1978) terms, serve as approximations that mediate our felt sense and associated mental (and artistic) processes. It is the creation of this personal and unique "tool" from internal conceptions, sensations and viscera, which ultimately turns into narratives by embodying what is re-presented as meanings into cognitive (written or spoken) material-in this case, teachers' creative narratives of identity.

“Forms of representation are posited as the devices through which ... personal concepts are made communicable ... the choice of a form of representation is a choice in the way the world will be conceived ..." (Eisner, 1980, p. 50) 
Nevertheless it must be recognized that the very starting point of a box as template for the self creates some practical and metaphorical strictures on "self" and self-exploration. Most particularly, there is the potentiality in using self-boxes for any self-study inquiry to confuse the artifice, the "thing" itself, with that which is ineffable-the abstract and dynamic (in)substance of self in imagination. The very characteristics (top, bottom, sides, inside, outside and centre) of the object itself reify and, therefore, while appropriating many possibilities, also inhibit particular self-conceptualizations or self-narratives that might otherwise be signified. And so, while there is demonstrable value in the use of this arts-based method for teacher self-study as an aid to individual and collective professional development and for its value in reinvigorating conceptions of the self, we must be alert to paradoxes that remain in the use of such a methodology for deepening and widening our theoretical conceptualizations of self and identity.

\section{Ending Fragment}

Behold! I survey the painted water lily, turning its fragile, fresh-painted, form, gently in my palm. The light of the evening sky enhances its fiery tints. The fluorescent, acrylics paint visual dance-like flames through the fronds. Fashioned from clay, suspended in water, living as fire, I muse. As near perfect as I can craft it, given my resources and artistic limitations but still woefully short of the ethereal perfection of the symbolic center conjured in my inner imaginings. I reflect on my own dissatisfaction and the impossible task of satisfactorily bringing a "sense" of something to literal expression. I must go easy on my disappointment, not run my well-worn, ancient pattern of self-depreciation which would lead to me binning the lot out of sheer frustration. "It's just a bit of amusement,"I tell myself in defense; "it's only a task, self-induced." Ready to place the lily at the centre, I construct the means to suspend it above the floor of the inner world of my self-box, so that it appears to float mid-space. The clay, still soft and fragile, rests uneasily on its plinth. Any knock would destabilize it. The first topple to the floor would shatter the frond-like petals into fragmented pieces, and end like a heap of bloody ribs exposed after roadkill. With dawning realization, it occurs to me that my water-lily centerpiece is just too vulnerable to exist in its intended site. Not just because of its physical fragility, which is undoubted, as the first petal snaps into my awkward hand when I try to secure it in situ. Fighting for attention in my consciousness, an insight intrudes - that, as a female head of a school of education, in a senior management role, in a UK university, I cannot possibly proceed with this installation at the centre of my self-box. In so doing, I risk exposing my delicate creation, my sense of inner self to all the potential rough and tumble expectations and demands of life 
at the political wheel of university teacher education. It wouldn't last ten minutes in this context. "Don't be silly,"I protest to myself."This is just a symbolic process; inward in direction, deeply private and with little to do with the outer world." Still, in some deeper place, doubts continue to pervade and the candor of their recognition will not be shaken off. Dazedly, I reach for white tissue paper and parcel my carefully wrought creation, my sense of center and soul and place it in another box for safekeeping. In the vacant interior of my self-box, I now place, numbly, an ersatz objet d'art as my foundation piece: a ceramic egg, polished, beautifully marbled and robust, impervious to destruction. Solid and reliable as I, too, must appear to the university world in my management power suit. I close the lid slowly, imperceptibly, on this interior world. There! No one will ever know.

...there are dimensions of your being and a potential for realization and consciousness that are not included in your concept of yourself. Your life is much deeper and broader than you conceive it to be here. What you are living is but a fractional inkling of what is really within you... (Campbell, 1988, p. 58)

\section{Notes}

1. Pseudonym agreed as part of ethical process.

\section{References}

Atkinson, D. (2002). Arts in education. Identity and practice, Netherlands: Kluwer Academic Press.

Biddulph, M. (2005). Mural-making as a methodology for understanding 'self'. In C. Mitchell, S. Weber, \& K. O'Reilly-Scanlon (2005) (Eds.), Just who do we think we are? Methodologies for autobiography and self-study in teaching. Oxford: RoutledgeFalmer, 49-57.

Bodone, F., Guojónsdóttir, H. \& Dalmau, M.C. (2004). Revisioning and recreating practice: Collaboration in J.J. Loughran et al.
(2004). International Handbook of SelfStudy of Teaching and Teacher Education Practices, 12. Netherlands, Springer, 743-784.

Buber, M. (1947/2007). Between man and man. London: Routledge.

Butler-Kisber, L. (2008). Collage as inquiry. In J.G. Knowles \& A.L. Cole (Eds.), Handbook of the arts in qualitative research: Perspectives, methodologies, examples, and issues. Thousand Oaks, CA: Sage, 265-276.

Campbell, J. (with Bill Moyers) (1988). The power of myth, New York: Doubleday. 
Coffey, P. (1999). The ethnographic self. London: Sage.

Cole, A.L. (1997). Impediments to reflective practice: towards a new agenda for research on teaching. Teachers and Teaching: Theory and Practice, 3(1), 7-27.

Conroy, J.C. (2007). The Estranged self: recovering some grounds for pluralism. Paper delivered at conference of the Association for Moral Education, November 15-17, 2007, New York University.

Derry, C. (2005). Drawing as a research tool for self-study. In C. Mitchell, S. Weber, \& K. O'Reilly-Scanlon (2005). (Eds.), Just who do we think we are? Methodologies for autobiography and self-study in teaching. Oxford: RoutledgeFalmer. 34-46.

Diamond, C.T.P. \& van Halen-Faber, D. (2005). Apples of change: arts-based methodology as poetic and visual sixth sense. In C. Mitchell, S. Weber, \& K. O'Reilly-Scanlon (2005). (Eds.), Just who do we think we are? Methodologies for autobiography and self-study in teaching. Oxford: RoutledgeFalmer, 81-94.

Eisner, E.W. (1988). The primacy of experience and the politics of method. Educational Researcher, 17(5), 15-20.

Frings Keyes, M. (1983). Inward journey: Art as therapy, La Salle \& London: Open Court.

Gergen, K. (1994). Realities and relationships. Soundings in social construction. Cambridge, MA: Harvard University Press.

Gergen, K. (2001). Self narration in social life. In M. Wetherell, S. Taylor, \& S.J. Yates (Eds.), Discourse theory and practice, London: Sage, 247-259.

Gergen, K. \& Gergen, M. (1988). Narrative and the self as relationship, In L. Berkowitz (ed.), Advances in Experimental and Social Psychology, 21, 17-5, New York: Academic Press.

Harrison, B. (2002). Photographic visions and narrative inquiry. Narrative Inquiry, 12(1), 87-111.

Heidegger, M. (1971). Poetry, language, thought. A. Hofstadter (Trans.). New York: Harper \& Row.

hooks, b. (1989). Talking back: thinking feminist, thinking black, Toronto: Between the Lines.
Janesick, V.J. (1998). Stretching exercises for qualitative researchers. Thousand Oaks, CA: Sage Publications.

Kalff, D. (1980). Sandplay: A psychotherapeutic approach to the psyche. Boston: Sigo Press.

Kotre, J. (1995). White gloves: How we create ourselves through memory, New York: The Free Press.

Leitch R. (2003). Journey into paradox: re-searching unconscious in teacher identity using creative narrative. Unpublished Doctoral thesis, University of Bristol, UK.

Leitch, R (2006). Limitations of language: developing arts-based creative narrative in stories of teachers' identities. Teachers and Teaching: Theory and Practice, 12(5), 549-569.

Lorenz, H.S. \& Watkins, M. (2001). Depth psychology and colonialism: Individuation, seeing through, and liberation. Retrieved October 22, 2008, from http://uploads.pacifica. edu/gems/creatingcommunityw/DepthP sychologyColonialism.pdf

Lorenz, H. \& Watkins, M. (2001). Part one: Silenced knowings, forgotten springs: Paths to healing in the wake of colonialism. Retrieved November 1, 2008, from http://www.mythinglinks.org/LorenzWatk ins 2 A.html

McMahon, P.L. (2000). From angst to story to research text: The role of arts-based educational research in teacher inquiry. Journal of Curriculum Theorizing, 16(1) 125-146.

Mitchell, C. \& Weber, S. (1999). Reinventing ourselves as teachers: Beyond nostalgia. London: Falmer Press.

Palmer, P.J. (1998). The Courage to teach: Exploring the inner landscape of a teacher's life. San Francisco: Jossey-Bass.

Piantanida, M., McMahon, P., \& Garman, N. (2003). Sculpting the contours of artbased educational research within a discourse community. Qualitative Inquiry, 9(2), 182-191.

Ronai, C.R. (1992). The reflexive self through narrative. Chapter 5 in C. Ellis \& M.G. Flaherty (eds.) (1992), Investigating subjectivity: Research on lived experience. London: Sage Publications. 
Sachs, J. (1999). Teacher professional identity: competing discourses, competing outcomes. Paper presented at AARE Conference, Melbourne, November 1999. Retrieved October 21, 1998, from http://www.aare.edu.au/99pap/sac99611. htm

Slattery, P. (2001). The Educational Researcher as Artist Working Within. Qualitative Inquiry, 7(3): 370-398.

Thomas, K. \& Morgan, J.M. (2002). Memory boxes, treatment and hope. International Conference on AIDS. Retrieved October 28, 2008 from http://gateway.nIm. nih.gov/MeetingAbstracts/ma?f=1022509 15.html
Vygotsky, L.S. (1978). Mind in society: The development of higher psychological processes. Cambridge, MA: Harvard University Press.

Wertsch, J.(2001). The multivoicedness of meaning. In M. Wetherell, S. Taylor, \& S.J. Yates (Eds.), Discourse theory and practice, London: Sage. 222-235.

Whitmore, D. (2000). Psychosynthesis counselling in action, London: Sage.

Zeichner, K. (2007). Accumulating knowledge across self-studies in teacher education. Journal of Teacher Education, 58(1), 36-46.



Ruth Leitch is a senior lecturer in the School of Education, Queen's University Belfast, Northern Ireland, where she has, until recently, been head of the School, prior to which she headed up the division for the Continuing Professional Development of teachers. She lectures in the areas of education in divided societies, the impact of trauma on children and adults and the transformational role of personal development in teacher education. Her research interests are teacher identity, children's voice and research methodologies associated with arts-based educational research. She is currently director for a nationally funded project that is consulting pupils and teachers on assessment initiatives and serves on the editorial board of five international journals. In 2004 she received the outstanding dissertation award by the Qualitative Research Special Interest Group of the American Educational Research Association (AERA) for her research on creative narratives of teacher identity. 